\title{
$\mathrm{Nd}-\mathrm{Fe}-\mathrm{B}$ 磁石の磁化反転過程に及ぼす 静磁気相互作用の影響 \\ 一計算機シミュレーション一
}

福 永博 俊 ${ }^{1}$ 桐野一生 ${ }^{2, *} \quad$ 中 野 正 基 ${ }^{1} \quad$ 柳 井 武 志 ${ }^{1}$

\author{
1長崎大学大学院工学研究科 \\ 2長崎大学大学院生産科学研究科
}

J. Japan Inst. Metals, Vol. 76, No. 1 (2012), pp. 43-47

Special Issue on Recent Progresses of Materials Science of Rare Earth Permanent Magnet Materials and Their Perspectives (C) 2012 The Japan Institute of Metals

\section{Effect of Magnetostatic Interaction on Magnetization Reversal Process in Nd-Fe-B Magnets Computer Simulation-}

\author{
Hirotoshi Fukunaga ${ }^{1}$, Kazuo Kirino ${ }^{2 *}$, Masaki Nakano ${ }^{1}$ and Takeshi Yanai ${ }^{1}$ \\ ${ }^{1}$ Graduate School of Engineering, Nagasaki University, Nagasaki 852-8521 \\ ${ }^{2}$ Graduate School of Science and Technology, Nagasaki University, Nagasaki 852-8521
}

\begin{abstract}
Magnetization reversal process of $\mathrm{Nd}-\mathrm{Fe}-\mathrm{B}$ sintered magnets was simulated based on the micromagnetic theory under consideration of the magnetostatic interaction and the cooperative effect of many grains. Reversal of magnetization was nucleated from magnetically soft grains. Then, the reversed region grew in the direction of applied field, and spread into the whole magnet when the applied field exceeded a critical value. The coercivity was decreased significantly by the existence of a small amount of magnetically soft grains, and did not depend on their fraction. Nonmagnetic inclusions between $\mathrm{Nd}_{2} \mathrm{Fe}_{14} \mathrm{~B}$ grains also initiated magnetization reversal and decreased the coercivity. These effects of magnetostatic interaction were especially significant for the magnets with well-aligned grain orientation, and limited the obtainable coercivity to approximately 0.7 of the anisotropy field even if the magnet was consisted of perfect grains segregated from each other.
\end{abstract}

(Received July 4, 2011; Accepted August 9, 2011; Published January 1, 2012)

Keywords: neodymium-iron-boron magnet, magnetization reversal, coercivity, magnetostatic interaction, computer simulation, micromagnetic theory

\section{1. は じめに}

$\mathrm{Nd}-\mathrm{Fe}-\mathrm{B}$ 磁石は電気電子機器等に広く使用されている が，その保磁力は $\mathrm{Nd}_{2} \mathrm{Fe}_{14} \mathrm{~B}$ 結晶の異方性磁界から期待され る值に比べてはるかに小さい. $\mathrm{Nd}-\mathrm{Fe}-\mathrm{B}$ 磁石の用途が広が るにつれて，その保磁力の改善が強く望まれるようになって いる1).

このような観点から, 結晶粒界の原子配列制御 2,3 , 粒界 近傍の磁気異方性の制御4,5), 粒界相の結晶構造制御6,7)等に よる保磁力の向上について多くの研究がなされている。これ らの手法による保磁力向上は，粒界近傍での磁化反転核の抑 制と粒界での磁化反転の伝搬抑制によると考えられる。例え ば，Li らは粒界相の非磁性化による磁化反転の伝搬抑制効 果が保磁力を増加させると報告している ${ }^{8)}$. 多数の結晶粒か ら構成される実用磁石に拈いては，低磁界で核発生する結晶 粒を完全に排除することには困難が伴うと予測されるので,

* 長崎大学大学院生 (Graduate Student, Nagasaki University)
核発生後の磁化反転領域の伝搬抑制は保磁力向上に極めて効 果的であると考えられる.

粒界相を非磁性化して結晶粒間の交換相互作用をなくした 磁石では，磁化反転過程は粒間の静磁気相互作用に影響され る. このような磁石に打ける保磁力と磁化反転過程を知るこ とは， $\mathrm{Nd}-\mathrm{Fe}-\mathrm{B}$ 磁石の潜在能力を評価する上で重要だと考 えられる。従来, 比較的少数の $\mathrm{Nd}_{2} \mathrm{Fe}_{14} \mathrm{~B}$ 結晶で構成される モデル磁石について，マイクロマグネティクス理論に基づい た計算機シミュレーションにより磁化反転過程が調べられて いる ${ }^{9,10)}$. しかしながら，静磁気相互作用が長距離の相互作 用であることを考慮すると，磁化反転過程の計算には多数の 結晶粒の集団的振る舞いを考慮する必要がある. 静磁気結合 した多数の磁性体に抢ける集団的振る舞いの重要性について は, $\mathrm{Fe}_{3} \mathrm{Pt}$ ナノワイヤーにおける磁化反転過程の研究でも指 摘されているところである11).

本研究では，交換結合のない 512 個の $\mathrm{Nd}_{2} \mathrm{Fe}_{14} \mathrm{~B}$ 結晶から 構成されるモデル磁石を用い，その磁化反転過程を計算機シ ミュレーションすることにより，磁化反転過程に及ぼす静磁 気相互作用の影響を調べると共に，粒界での交換結合を遮断 
した $\mathrm{Nd}-\mathrm{Fe}-\mathrm{B}$ 磁石のポテンシャルを明らかにした。

\section{2. 計算モデルおよび計算方法}

\section{1 モデル磁石}

計算機シミュレーションには, Fig. 1 に示すモデル磁石を 用いた. 磁石は 512 個の $\mathrm{Nd}_{2} \mathrm{Fe}_{14} \mathrm{~B}$ 立方体結晶から構成され, 1 個の結晶は 64 個の要素に分割されている. 磁気的劣化に より低保磁力となった結晶粒を模擬するために, 磁石内に軟 磁性結晶をランダムに配置した(Fig. 1 の白の部分). また, 結晶粒間に存在する非磁性介在物を模擬するために, $\mathrm{Nd}_{2} \mathrm{Fe}_{14} \mathrm{~B}$ 結晶粒間にランダムに非磁性要素を配置した.

本研究では, 結晶粒間の交換相互作用がない磁石を扱うの で，結晶粒界での交換定数は 0 とした。 また， $x, y, z$ 方向に は周期境界条件を設定し, 巨視的な反磁界が発生しないモデ ルとした。

$\mathrm{Nd}_{2} \mathrm{Fe}_{14} \mathrm{~B}$ 結晶の磁化容易軸が印加磁界方向となす方位角 $\theta$ は, 乱数を用いてその確率密度が,

$$
f(\theta)=\exp \left(-\frac{\theta^{2}}{2 \sigma^{2}}\right) \sin \theta / \int_{0}^{\pi / 2} \exp \left(-\frac{\theta^{2}}{2 \sigma^{2}}\right) \sin \theta d \theta
$$

となるように正規分布させた ${ }^{12)}$ 。ここで， $\sigma$ は標準偏差であ る. 印加磁界方向と垂直な面内での磁化容易軸の偏角 $\varphi$ は，乱数を用いてランダムに決定した。シミュレーションで は $\sigma$ を変化させることにより, 結晶の配向度を変化させ た. 結晶の配向度は, 各結晶の $\cos \theta$ の平均, $\langle\cos \theta\rangle$ で評価 した。

詳細な計算に先立ち, まず，要素サイズの保磁力に及ぼす 影響について検討した．完全配向 $(\langle\cos \theta\rangle=1)$ の磁石に 1.6 $\sim 2.0 \mathrm{vol} \%$ の軟磁性結晶を混入し, 要素サイズを $1.0 \mu \mathrm{m}$ か ら $0.25 \mu \mathrm{m}$ まで変化させて保磁力を計算し, 保磁力が変化 しないことを確認した．次に，結晶粒径を変化させることに より，要素サイズを $10 \mathrm{~nm}$ から $2 \mathrm{~nm}$ まで変化させて保磁力 を計算した．要素サイズが $2 \mathrm{~nm}$ の場合に保磁力が約 $10 \%$ 増加したが, 他の要素サイズでは保磁力への影響はなかっ た.これは, 保磁力が長距離の相互作用である静磁気相互作 用に支配されていることに起因すると考えられる．本報で は, 焼結磁石の粒径を考慮して, 要素サイズを $1 \mu \mathrm{m}$, 結晶 サイズを $4 \mu \mathrm{m}$ とした際の結果を示す. Table 1 にはシミュ レーションに用いた物理量を示している.

\section{2 計算方法}

磁気異方性, 交換, 印加磁界, 静磁気の各エネルギーを考 慮すると，モデル磁石に蓄えられる磁気エネルギー $W$ は,

$$
\begin{aligned}
W= & -K_{\mathrm{u}}^{(\mathrm{h})} \frac{V}{n} \sum_{i=1}^{n \times N}\left\{\frac{K_{\mathrm{u} i}}{K_{\mathrm{u}}^{(\mathrm{h})}}\left(\boldsymbol{u}_{i} \cdot \boldsymbol{m}_{i}\right)^{2}+\frac{S n^{1 / 3}}{6 K_{\mathrm{u}}^{(\mathrm{h})} V} \sum_{j=1}^{6} J_{i j}\left(\boldsymbol{m}_{i} \cdot \boldsymbol{m}_{j}\right)\right. \\
& \left.+\frac{M_{\mathrm{s} i}}{K_{\mathrm{u}}^{(\mathrm{h})}}\left(\boldsymbol{m}_{i} \cdot \boldsymbol{H}\right)\right\}+W_{\mathrm{m}}
\end{aligned}
$$

となる。ここで， $K_{\mathrm{u} i}, K_{\mathrm{u}}^{(\mathrm{h})}, M_{\mathrm{s} i}$ および $\boldsymbol{H}$ は，それぞれ， $i$ 番目の要素の異方性定数, $\mathrm{Nd}_{2} \mathrm{Fe}_{14} \mathrm{~B}$ 結晶の異方性定数, $i$ 番目の要素の飽和磁化および印加磁界である. $S$ および $V$ は結晶の表面積と体積, $n$ は結晶の分割数である。また， $J_{i j}$ は $i$ 番目の要素の周りにある要素 $j$ との間の交換定数である.

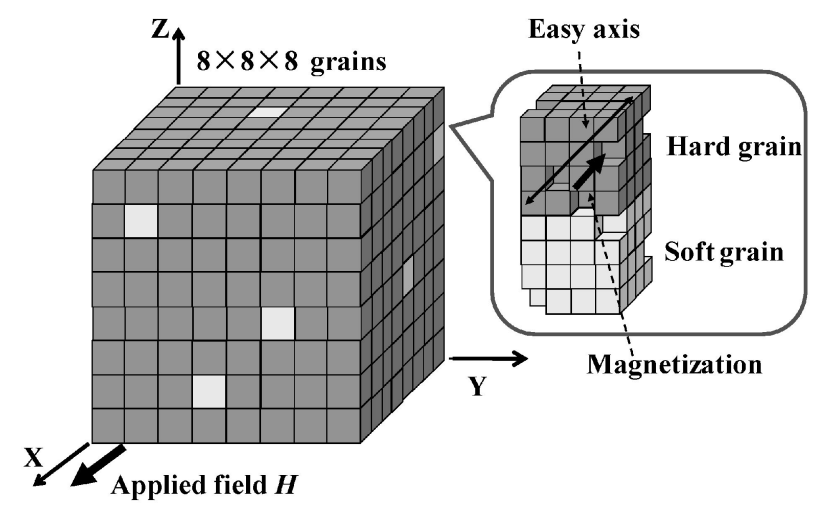

Fig. 1 Simulation model.

Table 1 Simulation parameters.

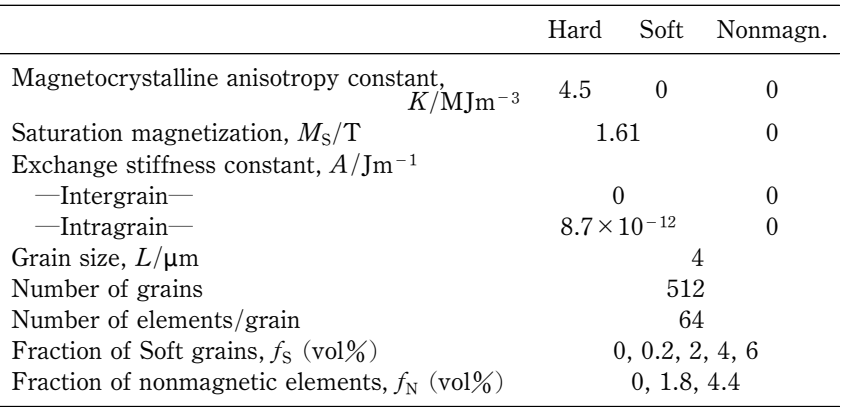

$J_{i j}$ の值は, 要素 $i$ と $j$ が同一の結晶粒に存在するときは Table 1 中の intragrain と表記された交換スティッフネス定 数 $A$ の值から，異なる結晶に存在するときは Table 1 中の intergrain と表記された $A$ の值から決定した ${ }^{13)}$. 後者の場合, $J_{i j}=0$ である. さらに, $\boldsymbol{u}_{i}, \boldsymbol{m}_{i}$ は磁化容易軸および磁化方向 の単位ベクトル， $W_{\mathrm{m}}$ は静磁気エネルギーである. 本研究で は，与えられた印加磁界に対して $W$ を極小とするように各 要素の磁化方向を決定し ${ }^{13)}$, モデル磁石に対する磁化曲線 を描くことにより磁化反転過程を検討した。

\section{3. 計算結果および議論}

\section{1 非磁性介在物が保磁力に及ぼす影響}

まず，非磁性介在物が保磁力に与える影響を検討した。 Fig. 2 には完全な配向 ( $\langle\cos \theta\rangle=1)$ の磁石の保磁力に及ぼす 非磁性要素の割合 $f_{\mathrm{N}}$ の影響を示す。2.1 節で説明したよう に, 非磁性介在物を模擬するために, 結晶粒間に非磁性要素 を配置して磁化反転過程を計算している。図中で磁界 $h$ と 磁化 $m$ は，それぞれ， $\mathrm{Nd}_{2} \mathrm{Fe}_{14} \mathrm{~B}$ の異方性磁界と飽和磁化で 規格化されている. Fig. 2 の挿入図に示すように，今回計算 した非磁性要素の量の範囲では, その存在により減磁曲線に 二段化が生じることはなかった．一方，規格化保磁力 $h_{\mathrm{c}}$ は, $f_{\mathrm{N}}$ の増加と共に徐々に減少し， $4.4 \mathrm{vol} \%$ の存在でお抢よそ 0.8 となった。保磁力の減少は非磁性要素近傍に発生する局 所反磁界によると考えられる.

\section{2 低保磁力結晶粒が保磁力に及ぼす影響}

完全配向 $(\langle\cos \theta\rangle=1)$ で $6 \operatorname{vol} \%$ の軟磁性結晶粒を含んだ 
モデル磁石に抢ける磁化分布を Fig. 3 に示す. 水色で示さ れた部分が軟磁性結晶粒である. Fig. 3(a)には, 減磁曲線 と軟磁性結晶粒周辺の反磁界分布を挿入している. 規格化印 加磁界 $h=-0.3$ に抢いて, 軟磁性結晶内の磁化が反転し, 減磁曲線の肩にくびれが生じた (Fig. 3(a)). 挿入図に見ら れるように, 磁化反転した軟磁性結晶粒と $\mathrm{Nd}_{2} \mathrm{Fe}_{14} \mathrm{~B}$ 結晶の 界面に磁極が発生し, 大きな反磁界が発生している. 印加磁 界と垂直な界面近傍では印加磁界々同方向の, 平行な界面近 傍では印加磁界を打ち消す方向の反磁界が発生している.

逆磁界を更に増加させると, 反転領域は印加磁界方向に徐 々に成長したが (Fig. 3(b)の桃色の部分), 逆磁界が臨界值 (保磁力)に達するまでは, 反転領域は軟磁性結晶近傍に限定 され, 磁石全体の磁化反転は生じなかった. 反転領域が磁界

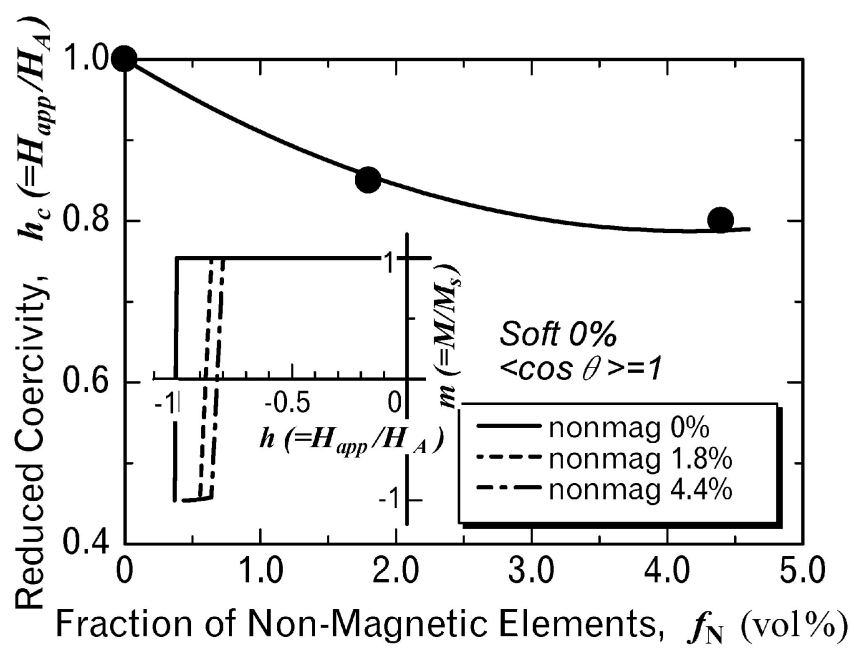

Fig. 2 Dependence of reduced coercivity $h_{\mathrm{c}}$ on fraction of nonmagnetic elements. The inset indicates demagnetization curves. The grains of the model magnets are perfectly aligned and the nonmagnetic elements are located on the grain boundaries.

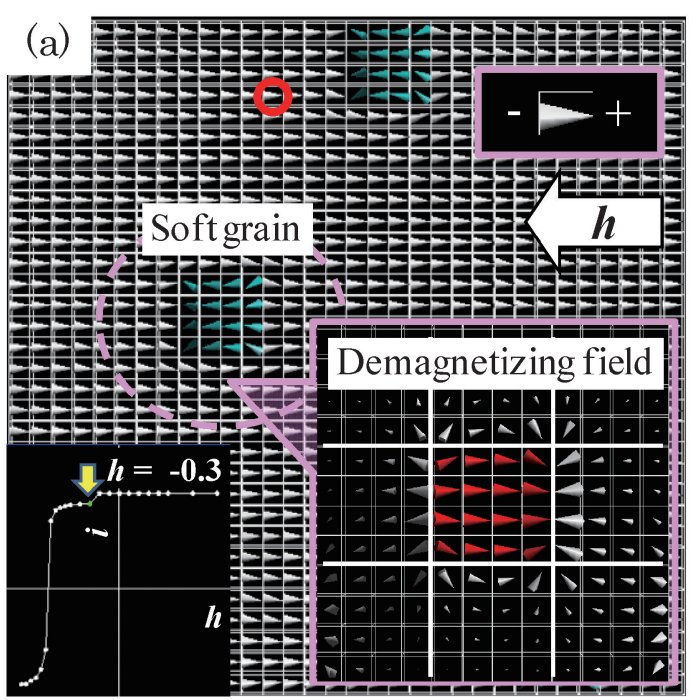

方向に成長する現象は，この領域で印加磁界と反磁界の方向 が一致するためである. 逆磁界が臨界值を超えると, 磁化反 転領域が一気に広がることで, 磁石全体の磁化が反転した.

この磁化反転過程のモデルを Fig. 4 に示している.ま ず, 軟磁性結晶とその近傍の磁化反転が生じ(1), その後反 転領域が磁界印加方向に成長する (2) . 逆磁界が臨界值 $h_{\mathrm{cr}}$ を超えると磁化反転領域が一気に広がって(3), 磁石全体の 磁化反転に至る.

Fig. 3(a)中の赤丸で示した要素の局所磁界(局所反磁界 $h_{\mathrm{d}}$ と印加磁界 $h_{\mathrm{app}}$ の和) と $h_{\mathrm{app}}$ の関係を Fig. 5 示している. 対 象の要素は, Fig. 4 の領域(2)の外側の領域にあり, (2) と接し ている. 図中の破線は $h_{\mathrm{app}}$ を示して抢り, 局所磁界の絶対 值 $\left|h_{\mathrm{d}}+h_{\mathrm{app}}\right|$ がこれより大きい際には印加磁界と同方向の, 小さい際には逆方向の局所反磁界が存在している. 図中 $h=$ -0.3 および -0.7 での $\left|h_{\mathrm{d}}+h_{\mathrm{app}}\right|$ の急激な変化は近傍の結晶

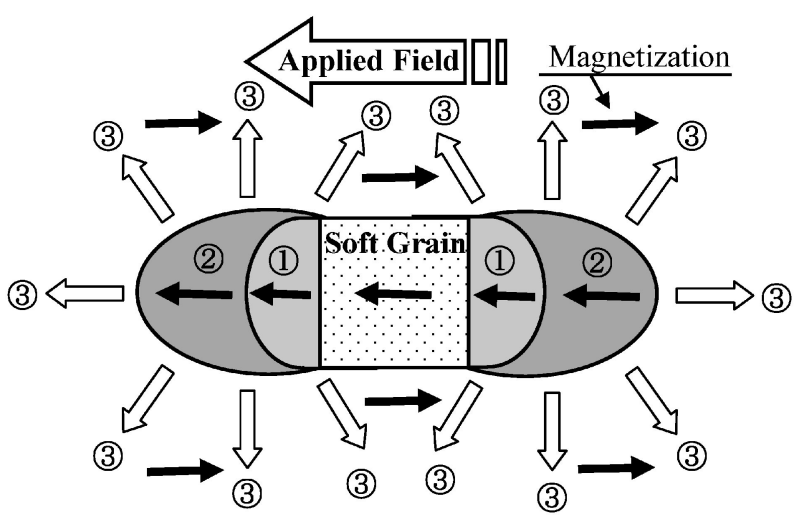

Fig. 4 Schematic representation of magnetization reversal process calculated for the magnet shown in Fig. 3. At first, the magnetization in Region-(1) is reversed with that in the soft grain. Then, the reversed region grows into Region-(2). Finally, the reversed region spreads out to the whole magnet as indicated by the arrows (3), when the reverse applied field exceeds a critical value.

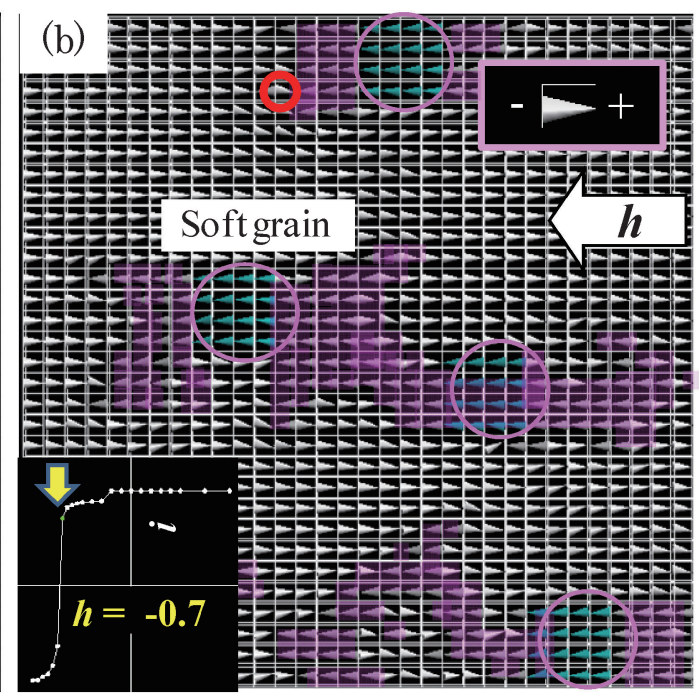

Fig. 3 Distributions of magnetization at (a) $h=-0.3$ and (b) $h=-0.7$, where $h$ is the reduced applied field. The grains of the model magnet is perfectly aligned and the fraction of magnetically soft grains is $6 \mathrm{vol} \%$. The blue arrows indicate distribution of magnetization in a soft grain, and the pink parts in (b) indicate the regions in which magnetization is reversed. The demagnetization curves are shown in the insets of (a) and (b). The distribution of demagnetizing field in the vicinity of a soft grain is also shown in the inset of (a). The variation of demagnetizing field at the element shown by the red circle is shown in Fig. 5. 


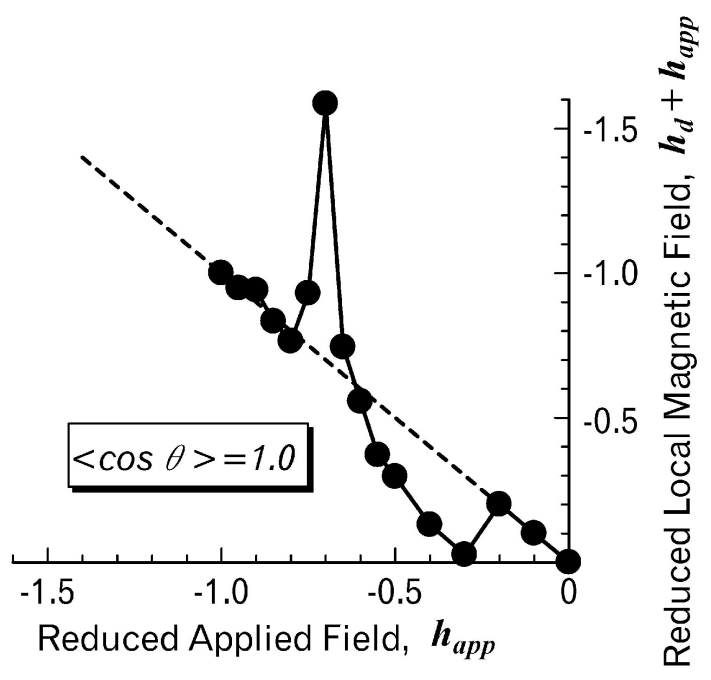

Fig. 5 Typical variation of local magnetic field in the element shown by the red circle in Fig. 3 as a function of reduced applied field $h_{\text {app }}$. The local field was deduced from the sum of $h_{\text {app }}$ and the reduced local demagnetizing field $h_{\mathrm{d}}$. The broken line in the figure indicates the variation of $h_{\text {app }}$.

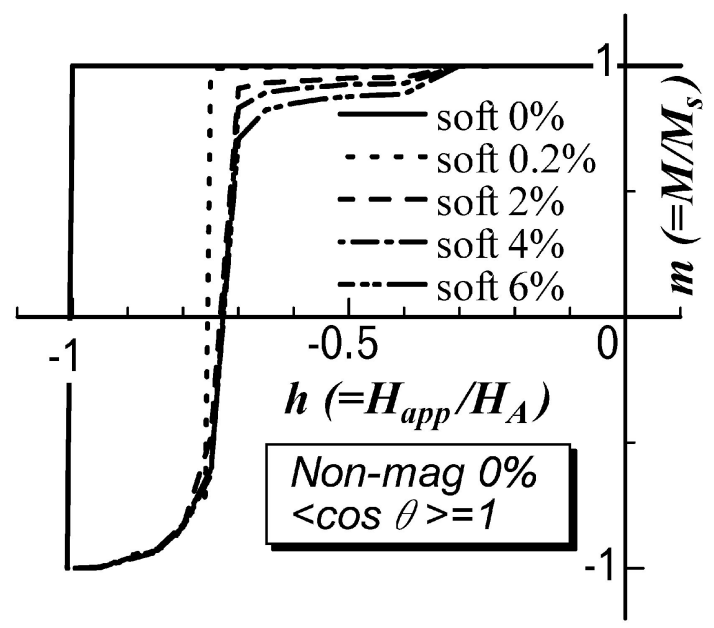

Fig. 6 Variation of demagnetization curves with fraction of magnetically soft grains. The applied field $h$ and the magnetization $m$ are reduced by the anisotropy field and the saturation magnetization of $\mathrm{Nd}_{2} \mathrm{Fe}_{14} \mathrm{~B}$, respectively.

の磁化反転による変化である. 図に見られるように, 逆磁界 が -0.7 程度まで増加したときに, 局所反磁界 $h_{\mathrm{d}}$ が一気に 増加して, $\left|h_{\mathrm{d}}+h_{\mathrm{app}}\right|$ が異方性磁界を越え, 磁石全体の磁化 反転に至っている．このことより， $h_{\mathrm{cr}}$ が既反転の領域が作 る局所反磁界により決定されていることが了解される．軟磁 性結晶の量を変化させて磁化反転を解析した結果, 軟磁性結 晶の量にかかわらず，同様な過程で磁化の反転が起こった.

Fig. 6 には，軟磁性結晶の割合 $f_{\mathrm{S}}$ を変化させた際の減磁 曲線の変化を示している。 $f_{\mathrm{S}}$ が増加するにつれて減磁曲線 の二段化が顕著になったが， $f_{\mathrm{S}}$ が $0.2 \sim 6 \mathrm{vol} \%$ 範囲では, 保磁力はほとんど変化しなかった．これは，| $\left|h_{\mathrm{d}}+h_{\mathrm{app}}\right|$ が一 気に増加する臨界逆磁界 $h_{\mathrm{cr}}$ が常に一定であることを意味し ている.

保磁力の $f_{\mathrm{S}}$ 依存性を整理して Fig. 7 に示している. 図に は非磁性要素が存在する場合の結果も示しているが, 軟磁性

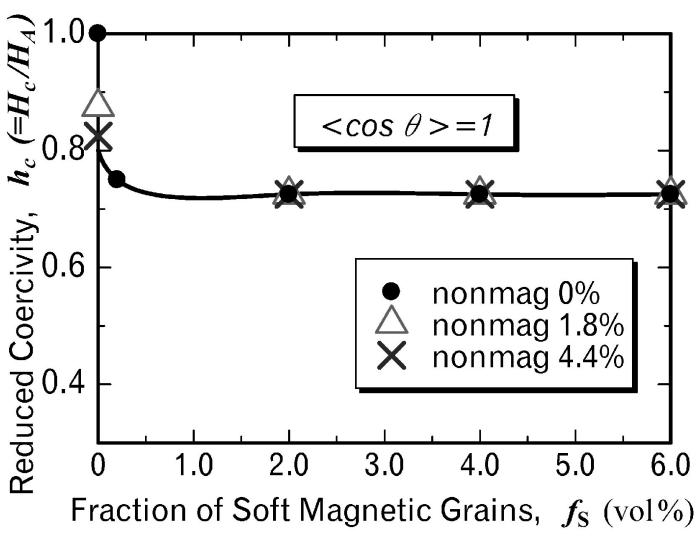

Fig. 7 Dependence of reduced coercivity on fraction of magnetically soft grains. The fraction of nonmagnetic elements was varied between 0 and $4.4 \mathrm{vol} \%$.

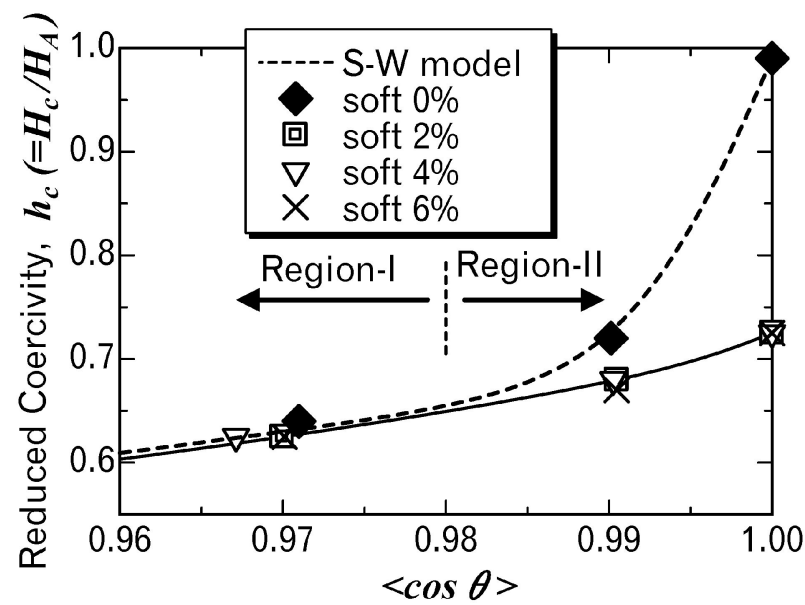

Fig. 8 Dependence of reduced coercivity on the alignment of the easy direction of magnetization, $\langle\cos \theta\rangle$. The reduced coercivity calculated by the $\mathrm{S}-\mathrm{W}$ model is also shown by the broken line as a reference.

結晶が存在しないときを除いて，保磁力は非磁性要素の量に は依存しなかった。また，非磁性要素の有無にかかわらず， 僅かな軟磁性結晶の存在が保磁力を著しく低下させた．これ らのことより, 僅かな低保磁力結晶粒の存在が保磁力を著し く低下させることが了解される.

$\mathrm{Nd}-\mathrm{Fe}-\mathrm{B}$ 系の磁石の保磁力 $H_{\mathrm{c}}$ については,

$$
H_{\mathrm{c}}=c H_{\mathrm{A}}-N M_{\mathrm{s}} / \mu_{0}
$$

が成立すると報告されている14,15)。ここで， $c, H_{\mathrm{A}}, M_{\mathrm{s}}$ 抢よ び $N$ は，それぞれ， $\mathrm{Nd}_{2} \mathrm{Fe}_{14} \mathrm{~B}$ 結晶の不完全さに基づく異方 性磁界の等価的減少率, 異方性磁界, 飽和磁化抢よび等価反 磁界係数である. Fig. 6,7 に示された結果から, 軟磁性結 晶を含む磁石について $N$ を計算すると， 1.23 となった．こ の結果は, 焼結 $\mathrm{Pr}-\mathrm{Fe}-\mathrm{B}$ 磁石に対して, 広沢らによって実 験的に決定された值と打よと一致している16).

\section{3 磁化容易軸の配向度が保磁力に及ぼす影響}

Fig. 8 に保磁力の磁化容易軸の配向度 $\langle\cos \theta\rangle$ 依存性を示 す。図中には, 磁石が $\mathrm{Nd}_{2} \mathrm{Fe}_{14} \mathrm{~B}$ 結晶のみで構成されるとし て Stoner-Wohlfarth モデル17)によって計算した結果も併せ 
て示している. 図に見られるように, 保磁力は $\langle\cos \theta\rangle$ 増 加と共に増加する傾向にある。軟磁性結晶を含まない磁石に 対する結果は, Stoner-Wohlfarth モデルによる結果と一致 したが，軟磁性結晶粒を含む磁石では静磁気結合により保磁 力が低下する傾向が見られた. Stoner-Wohlfarth モデルに よる結果との差は，〈 $\cos \theta\rangle$ が 0.97 以上で特に顕著となり, $\langle\cos \theta\rangle$ を 0.97 以上にしても，保磁力はほとんど改善されな い結果となった.

以上の振る舞いは，3.2 節での結果を考慮することによ り，以下のように説明できる．配向度が高く(〈 $\cos \theta\rangle$ 大゙大き く)軟磁性結晶が存在する磁石では，まず，軟磁性結晶近傍 の磁化が反転し, その後, 逆磁界が $h_{\mathrm{cr}}$ に達したとき, 磁化 の反転領域が一気に磁石全体へと広がる(Fig. 4). Fig. 5 の 説明で述べたように， $h_{\mathrm{cr}}$ は既に反転した領域が作る局所反 磁界により決定され打り，約 $-0.65 \sim-0.7$ と軟磁性結晶の 量や配向にはあまり依存しない。したがって, 高配向の磁石 に抢いては，その保磁力は $h_{\mathrm{cr}}$ に支配されて抢り，保磁力が これを越えることはない。すなわち， $h_{\mathrm{cr}}$ が粒間の交換結合 が遮断され少量の低保磁力結晶を含む磁石における保磁力の 限界值を与える。

一方, 配向度の悪い $(\langle\cos \theta\rangle$ が小さい)磁石では, 磁化容 易軸が印加磁界方向から大きく傾いている結晶が多数存在す る. Stoner-Wohlfarth モデルから予測されるように，これ らの結晶の保磁力 $h_{\mathrm{cn}}$ は小さい(Fig. 8 の破線参照). $h_{\mathrm{cn}}$ が $h_{\mathrm{cr}}$ より小さい場合には, 逆磁界が $h_{\mathrm{cr}}$ に達する前に, これ らの結晶の保磁力 $h_{\mathrm{cn}}$ に達し, これらの結晶で磁化反転が生 じて磁石全体の磁化反転へと繋がる。このため，保磁力は Stoner-Wohlfarth モデルによる值とお抢よそ一致すること になる.すなわち, Fig. 8 の Region-I では, StonerWohlfarth 型の磁化回転により, Region-II では, 既反転領 域が作る反磁界により保磁力が決定されている.

なお，実用磁石では，配向を改善すると保磁力が低下する 傾向にあると言われている，上記の解析結果は，結晶粒間の 交換相互作用を完全に遮断した場合, 配向改善による保磁力 低下を抑制できる可能性も示唆している.

\section{4. ま め}

結晶粒間の交換相互作用が遮断された $\mathrm{Nd}-\mathrm{Fe}-\mathrm{B}$ 磁石の磁 化反転過程を, 多数の結晶粒の集団的振る舞いを考慮して, マイクロマグネティクス理論に基づく計算機シミュレーショ
ンにより研究した。主な結果は以下のように要約される. 磁石に含まれる非磁性介在物や軟磁性結晶は, 磁化反転核 の発生に寄与し, 磁石の保磁力を低下させた. 両者が共に存 在する磁石では, 軟磁性結晶の存在が支配的となり, 保磁力 は非磁性介在物の量には依存しなかった，軟磁性結晶から発 生した磁化反転領域は, 逆磁界の増加とともに磁界印加方向 にわずかに成長するが，反転磁界が臨界值に達するまでは， 磁石全体に広がることはなかった。反転磁界が臨界值を越え ると, 反磁界と逆磁界の和が異方性磁界を越え, 磁石全体の 磁化が一気に反転した。配向度の高い磁石では，0.2 vol\%の 軟磁性結晶の存在のみで保磁力が著しく低下し, 僅かな低保 磁力結晶の存在が磁石特性を損なうことが明らかとなった.

静磁気相互作用による保磁力の低下は, 配向度の高い磁石 で顕著となり，配向度 $\langle\cos \theta\rangle$ が 0.97 以上では規格化保磁力

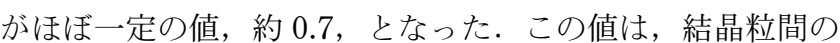
交換結合が遮断され, 極少量の低保磁力結晶を含む $\mathrm{Nd}-\mathrm{Fe}-$ $\mathrm{B}$ 磁石に打ける保磁力の上限值となる.

\section{文献}

1) For example, S. Sugimoto: Magn. Jpn. 6(2011) 81-88.

2) F. Vial, F. Joly, E. Nevalainen, M. Sagawa, K. Hiraga and K. T. Park: J. Magn. Magn. Mater. 242-245(2002) 1329-1334.

3) T. Akiya, H. Kato, M. Sagawa and K. Koyama: IOP Conf. Series: Mater. Sci. Eng. 1(2009) 012034.

4) H. Nakamura, K. Hirota, T. Minowa and M. Honshima: IEEE Trans. Magn. 42(2006) 2909-2911.

5) D. S. Li, S. Suzuki, T. Kawasaki and K. Machida: Jpn. J. Appl. Phys. 47 (2008) 7876-7878.

6) Y. Shinba, T. J. Konno, K. Ishikawa, K. Hiraga and M. Sagawa: J. Appl. Phys. 97 (2005) 053504.

7) W. Mo, L. Zhang, Q. Liu, A. Shan, J. Wu and M. Komuro: Scr. Mater. 59(2008) 179-182.

8) W. F. Li, T. Ohkubo, T. Akiya, H. Kato and K. Hono: J. Mater. Res. 24(2009) 413-420.

9) T. Schrefl, H. F. Schmidts, J. Fidler and H. Kronmiiller: J. Appl. Phys. 73 (1993) 6510-6512.

10) D. Süss, T. Schrefl and J. Fidler: IEEE Trans. Magn. 36(2000) 3282-3284.

11) D. Sun, J. Gao, X. Zhang, Q. Zhang, W. Hei, Y. Sun and Z. Cheng: J. Magn. Magn. Mater. 321(2009) 2737-2741.

12) H. Fukunaga and H. Nakamura: IEEE Trans. Magn. 36 (2000) 3285-3287.

13) H. Fukunaga, J. Kuma and Y. Kanai: IEEE Trans. Magn. 35 (1999) 3235-3240.

14) M. Sagawa and S. Hirosawa: J. Mater. Res. 3(1988) 45-54.

15) K. D. Durst and H. Kronmüller: J. Magn. Magn. Mater. 68 (1987) 63-75.

16) S. Hirosawa and M. Sagawa: J. Appl. Phys. 64(1988) 55535555.

17) E. C. Stoner and E. P. Wohlfarth: R. Soc. London A 240 (1948) 599-642. 